\title{
OBSERVATIONS ON THE SNOW LINE IN THE PERUVIAN ANDES
}

\author{
By Stefan L. Hastenrath \\ (University of Wisconsin, Milwaukee, Wisconsin, U.S.A.)
}

\begin{abstract}
Observations on both the modern and Pleistocene snow lines were made during a journey through the Peruvian Andes. En route observations were supplemented by an evaluation of air photographs in the Servicio Aerofotográfico Nacional in Lima and a survey of the literature. The large-scale variation of the Pleistocene snow-line depression is discussed with respect to possible palaeoclimatic implications.
\end{abstract}

RÉsumé. Observations de la ligne de neige dans les Andes du Pérou. Des observations des lignes de neige à la fois moderne et du pléistocène ont été effectuées pendant un voyage dans les Andes du Pérou Les observations faites en route ont été complètées par des évaluations faites sur des photographies aériennes du Servicio Aerofotográfico Nacional de Lima et par une compilation bibliographique. La variation à grande échelle de la dépression de la ligne de neige pléistocène est discutée en rapport avec des implications paléoclimatiques.

Zusammenfassung. Beobachtungen über die Schneegrenze in den peruanischen Anden. Auf einer Reise durch die peruanischen Anden wurden Beobachtungen über die heutige und die pleistozäne Schneegrenze angestellt. Die Reisebeobachtungen wurden durch eine Auswertung von Luftaufnahmen im Servicio Aerofotográfico Nacional in Lima und die Durchsicht der vorhandenen Literatur ergänzt. Die grossräumige Änderung der pleistozänen Schneegrenzdepression wird im Hinblick auf ihre mögliche paläoklimatische Bedeutung diskutiert.

\section{INTRODUGTION}

On the occasion of a field trip in Peru during July i 964 , observations were made on the modern and Pleistocene snow lines. The main purpose of the field work, organized by the Meteorology Department of the University of Wisconsin, was a study of the barchan dunes near Arequipa, southern Peru. The return journey to Lima was by motor convoy on a route through the Andes (Fig. I). Altimeter readings were taken en route and the elevations of the snow line and other geomorphic phenomena were estimated on that basis. These cursory observations en route were later supplemented by information in the present literature and by a survey of the available air photographs in the Servicio Aerofotográfico Nacional in Lima.

\section{Observations on Modern and Pleistocene Snow Lines in Southern Peru}

The present snow line on the volcanoes El Misti (lat. $16^{\circ} 17^{\prime}$ S.) and Chachani, in the Arequipa region, appears to be situated at more than $5,800 \mathrm{~m}$. The air photograph of El Misti (Fig. 2) shows a marked asymmetry, the snow line being lowest on the south-western flanks and highest on the north-east. Possible implications of this asymmetry will be discussed briefly below.

From Arequipa, a steep road winds up to the Altiplano at a level of more than 4 , ooo m. Near the very rim of the Altiplano, the road passes an extended salt pan, known locally as "El Salar". Nearby a well-developed cirque was found at an elevation of approximately $4,500 \mathrm{~m}$. (Fig. 3), which value provides a rough estimate for the Pleistocene snow-line elevation. On the basis of these observations, the Pleistocene snow-line depression in the Arequipa region can be estimated at about $\mathrm{I}, 300 \mathrm{~m}$.

This agrees well with reports of Brüggen (1929) from northern Chile. According to Brüggen, neither Tacora (5,950 m.) at lat. $17^{\circ} 24^{\prime} \mathrm{S}$. nor Llullaillaco $(6,700 \mathrm{~m}$.) at about lat. $24^{\circ} \mathrm{S}$. have perennial snow. From the occurrence of cirques, Brüggen estimated the Pleistocene snow line of Tacora volcano at about $5,000 \mathrm{~m}$.

Proceeding southward from Arequipa to the hyperarid regions of northern Chile, a rise of the modern snow line is indicated (see also Fig. 7). Pleistocene cirques were observed at about $4,500 \mathrm{~m}$. at about lat. $16^{\circ} \mathrm{S}$., while Brüggen reported cirques around the 5,00o $\mathrm{m}$. 


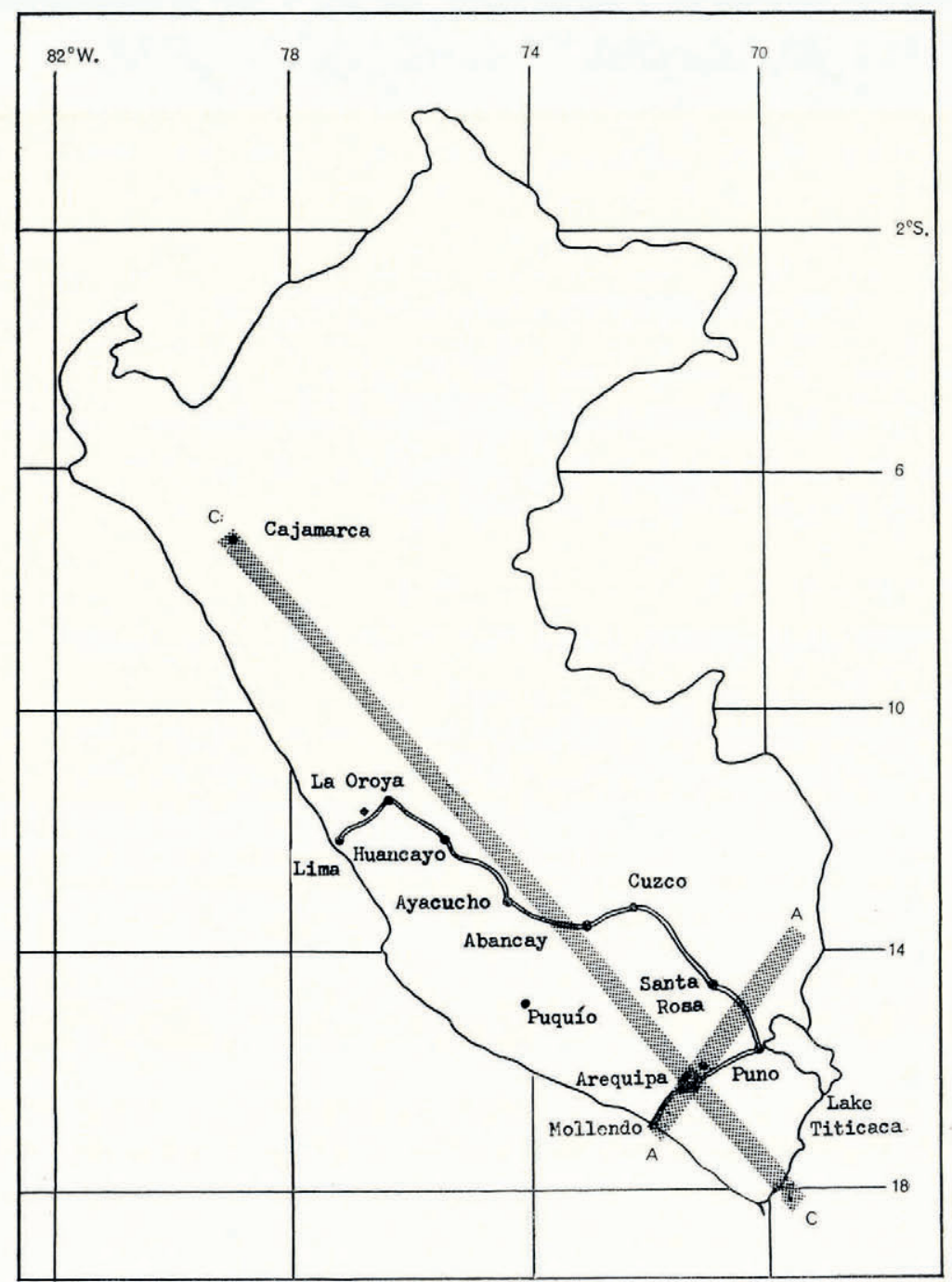

Fig. I. Map of Peru showing the travel route between Arequipa and Lima. A-A: the position of the south-south-west to north-north-east transect between Arequipa and the eastern Andes (Fig. 4); $C-C$ : the position of the north-west to south-east transect along the western Cordillera (Fig. 6); the location of the air photograph of El Misti (Fig. 2) and the locations of the photographs of Figures 3 and 5 are also shown

level from Tacora in lat. $17^{\circ} 24^{\prime} \mathrm{S}$. A southward rise of the Pleistocene snow line appears to be in general agreement with the behavior of the modern snow line.

On the eastern flank of the Andes, the modern snow line is found at much lower elevations than on the arid Pacific slopes of southern Peru. In the region of Santa Rosa, between Lake Titicaca and Cuzco, the base of the fresh snow was at about $4,600 \mathrm{~m}$. For the Cordillera de Vilcanota, Newell (1949) gave the recent snow line an elevation of about $4,900 \mathrm{~m}$. In the mountains to the north-east of Lake Titicaca, i.e. the Cordillera de Apolabamba, Cordillera de Muñecas and Cordillera Real, the recent snow line, according to Newell, lies between 4,900 and 5, I50 m. In the eastern ranges of the Andes the snow line is 


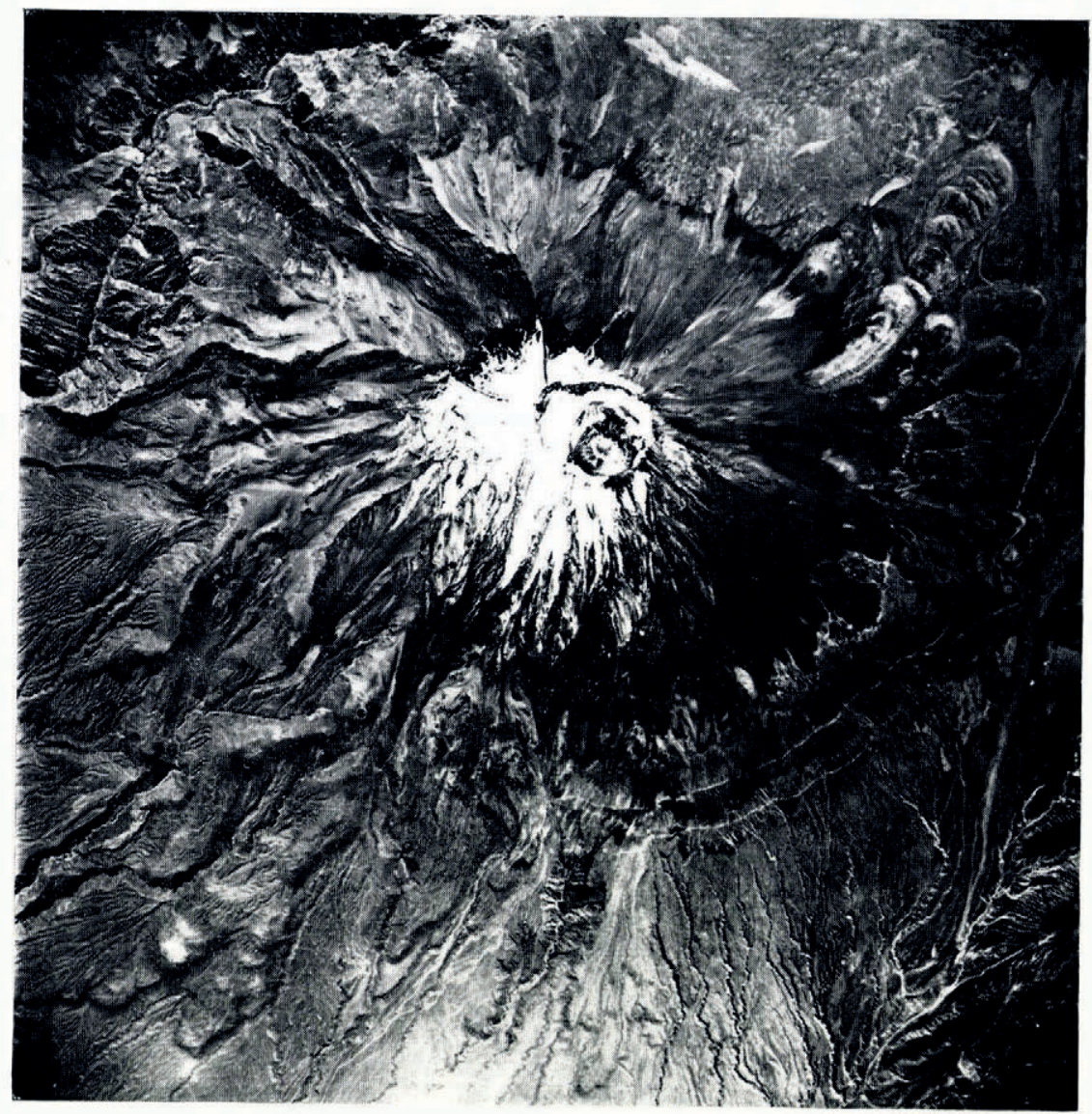

Fig. 2. Air photograph of El Misti (No. I1,133; July 1955; Servicio Aerofotográfico Nacional, Lima)

then found at a much lower elevation than on the arid Pacific side of the Altiplano. Air photographs from the region of the Cordillera de Vilcanota also indicate a tendency for the snow line to be lower on the eastern than on the western slopes.

In attempting to trace the elevation of the Pleistocene snow line from the arid Pacific slopes to the humid eastern slopes of the Andes, some further observations of Newell ( 1949 ) are relevant. North-east of Lake Titicaca, in the area of Huancané and Moho, Newell found cirques at elevations of 4,200-4,300 $\mathrm{m}$.

These observations are summarized in a tentative form in a schematic south-south-west to north-north-east transect from the arid Pacific coast to the Amazonian slopes of the Andes (Figs. 4 and $\mathrm{I}$ ). The modern snow line drops from more than $5,800 \mathrm{~m}$. in the arid coastal region to below $5,000 \mathrm{~m}$. on the humid Amazonian slopes. The Pleistocene snow line is estimated at 4,500 m. on the Pacific side of the Altiplano, falling off to about 4,200 m. in the eastern ranges. In other words, the Pleistocene snow-line depression decreases from about $\mathrm{I}, 300 \mathrm{~m}$. in the arid coastal region to about $700 \mathrm{~m}$. in the eastern part of the Andes.

Further information on the spatial distribution of the modern and the Pleistocene snow lines is provided by the observations of Troll (Troll and Finsterwalder, r935) in the Bolivian part of the Altiplano. The modern snow line on the western slopes of the Illampú-Hankouma 


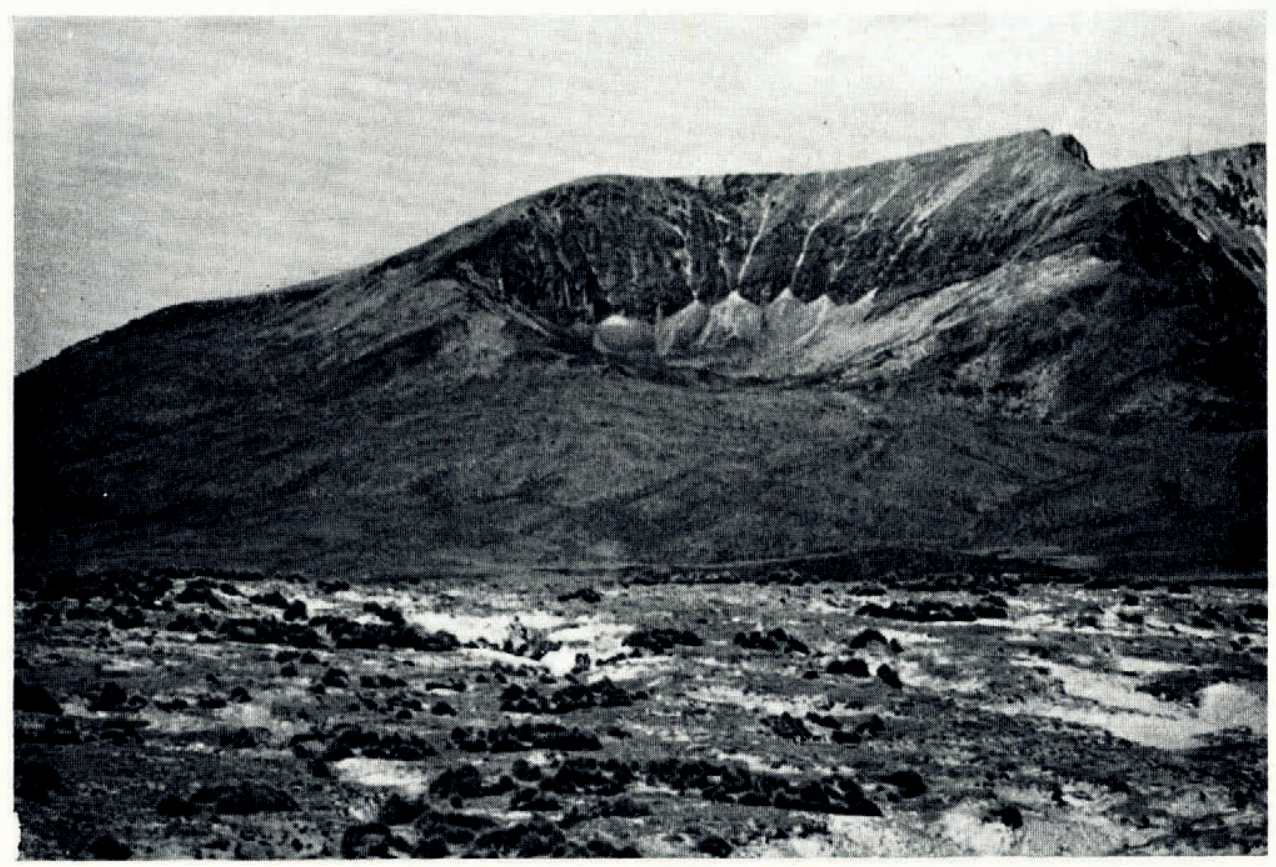

Fig. 3. Cirque at 4,500 m. near "El Salar" north-east of Arequipa. (Photograph by S. Hastenrath, July 1964)

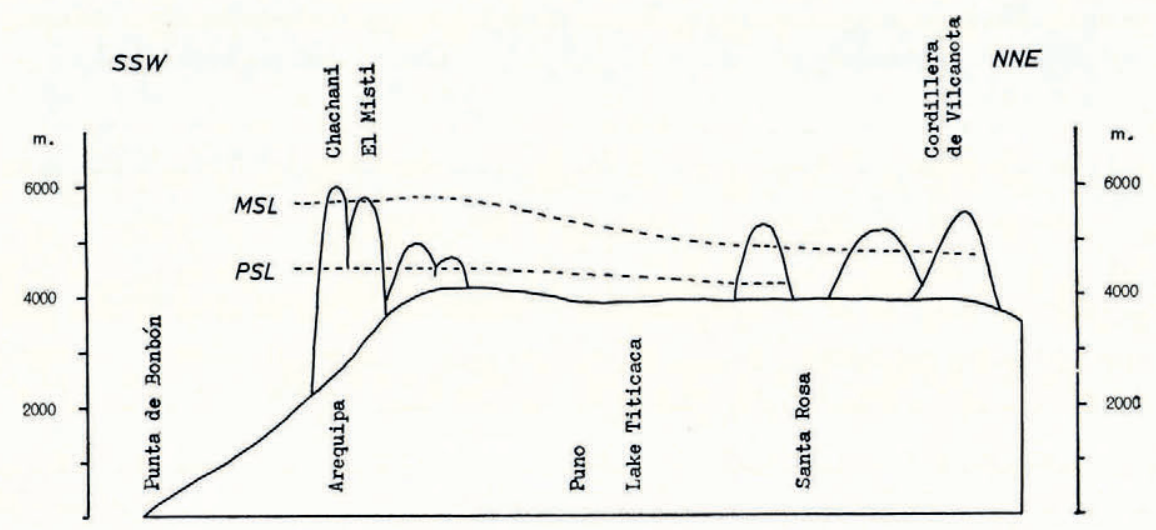

Fig. 4. Schematic south-south-west to north-north-east transect from the Pacific coast to the eastern Andes. MSL modern snow line, PSL Pleistocene snow line; vertical exaggeration times 25. For the orientation of the profile see Figure I

mountains is estimated at about $5,300-5,400 \mathrm{~m}$. and the Pleistocene snow-line depression at about $65^{0}-680 \mathrm{~m}$. Towards the arid interior of the Altiplano, on Chearcollo, the Pleistocene snow line rises to about $4,900 \mathrm{~m}$.

The asymmetry of the modern snow line, as evident on the air photographs (Fig. 2), might suggest that the climatic snow line rises a little from the Pacific side towards the interior of the Altiplano before dropping to lower elevations in the eastern Andes. The behavior of the local snow line on El Misti and Chachani might suggest a moisture supply from the Pacific Ocean. However, this particular asymmetry of the snow line may only be a local feature. 
Based on the work of Herzog (I9I4) and Troll (r929, I93 I), Ahlfeld (1946) has discussed the asymmetry of the snow line between the east and west slopes in the Cordillera Real of Bolivia. The daily cycle of convection and cloudiness accounts for decreased insolation during the afternoon hours. A similar effect might contribute to the asymmetry of the snow line as observed on the volcanoes of El Misti and Chachani.

\section{Observations in Central and Northern Peru}

Our observations on the modern and Pleistocene snow lines in southern Peru are also in general agreement with information available from the adjacent regions to the north. In the area of Nazca and Puquío at about lat. $15{ }^{\circ}$ S., Tricart (1965) has inferred a "Würm I" snow line at $4,300-4,400 \mathrm{~m}$. from a variety of geomorphological observations. Between Vilca and Yauricocha, i.e. south-west of Huancayo at about lat. $12.5^{\circ} \mathrm{S}$., Heim (1948) has estimated the Pleistocene snow-line elevation at about $4,300 \mathrm{~m}$. The present snow line appears to lie around 5,200 m., according to the data given by Heim.

A very interesting part of the journey was the stretch of country between La Oroya and Lima. The road rises to elevations of about $4,800 \mathrm{~m}$. (La Cima) in the western Cordillera, before leading down in a rapid descent to Lima on the coast. In this part of the western Cordillera, a glacier tongue was observed to descend to about 4,700 m. (Fig. 5). The climatic snow line at the latitude of Lima appears to lie around 5,000 m. (see also James (1959)). Cirque morphology was observed at elevations around 4,300 $\mathrm{m}$.

In the Cordillera Blanca of northern Peru, the recent snow line is at about the $5,000 \mathrm{~m}$. level (Kinzl, 1935, I949; Kinzl and Schneider, 1950). Kinzl (1935) stated there is a decrease of the snow-line elevation eastward, with heights of $5,150 \mathrm{~m}$. in the Cordillera Negra, $5,100 \mathrm{~m}$. on the western and 4,900 $\mathrm{m}$. on the eastern slopes of the Cordillera Blanca, and an elevation of only $4,75^{\circ} \mathrm{m}$. on the Nevado de Acrotambo, to the east of the Río Marañon.

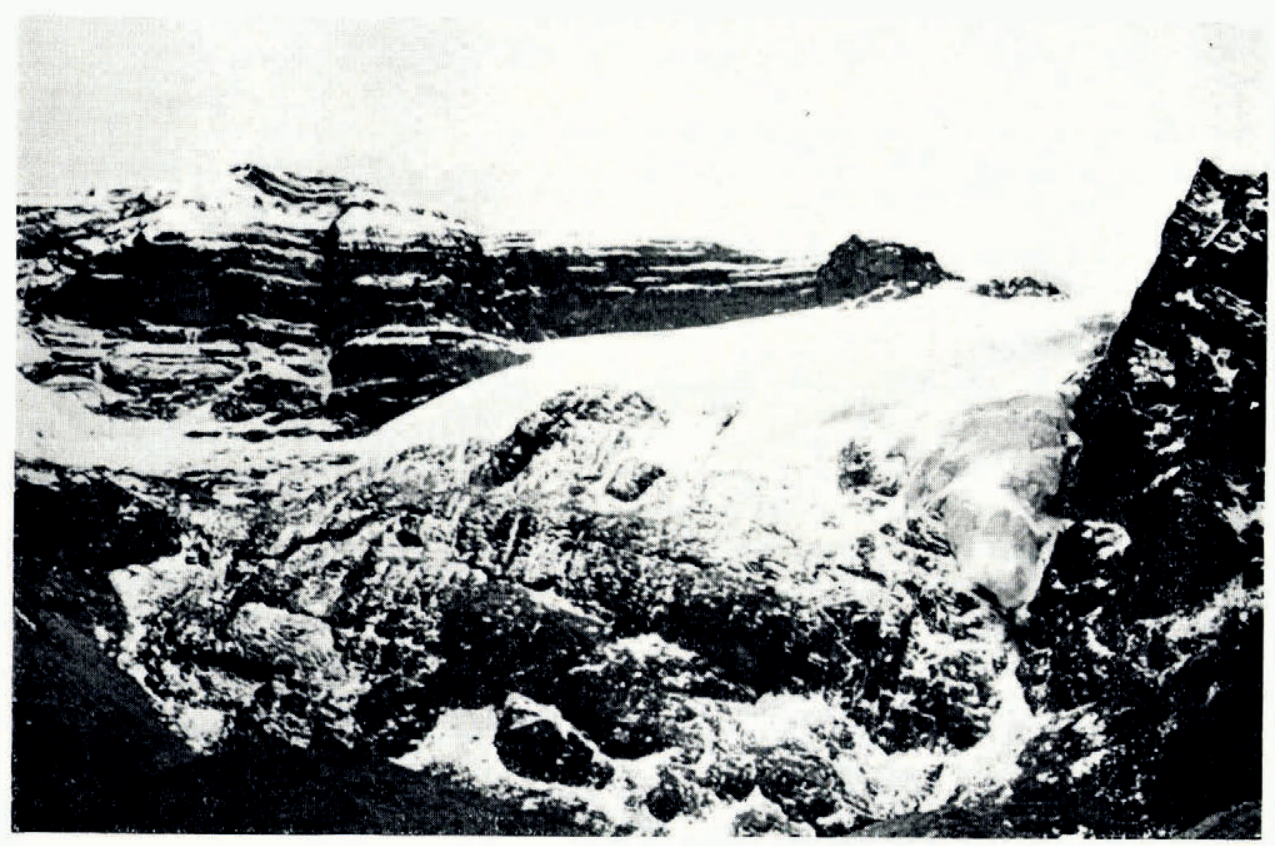

Fig. 5. Glacier tongue at 4,700 $\mathrm{m}$. in the western Cordillera between La Oroya and Lima. (Photograph by S. Hastenrath, July 1964 ) 
Kinzl (1935, and in press) estimated the Pleistocene snow-line depression in the Cordillera Blanca at about $600-700 \mathrm{~m}$.

For the region of Quiches, Río Marañon and the Ndo. de Pelegatos (4,928 m.), north of the Cordillera Blanca in about lat. $8 \cdot 3^{\circ} \mathrm{S}$., there are some observations of Heim (1948). The Pleistocene snow line is estimated at $4,000 \mathrm{~m}$. and the present snow line at $4,800 \mathrm{~m}$. For the area of Cajamarca, at about lat. $7^{\circ} \mathrm{S}$., Tricart (1965) set the "Würm" snow line at 3,700 $\mathrm{m}$. Nearer the Equator, in Ecuador, the recent snow line in the western Cordillera remains below 5,000 m. (Eichler, I952).

\section{Age of the Pleistocene Glacial Phenomena}

Machatschek (I944) has discussed the problem of Quaternary tectonic activity, a matter of some importance with respect to the depression of the present snow line. Machatschek has given evidence for a continuation of the Pliocene tectonic activity over large parts of the Andes. However, he found that the major part of the uplift has to be dated as prior to the penultimate glaciation, and that elevations during the last two glaciations were approximately equal to the present conditions. Tricart (1965) has in fact reported a possible "Riss" glaciation in the Nazca-Puquío area. Tricart has concluded that the "Riss" glaciation was more extensive than the "Würm" glaciation, which in general appears to agree with Machatschek's (1944) findings. Geomorphic evidence of the Pleistocene snow line as referred to here is understood as belonging to the last glaciation, because of the freshness of land forms.

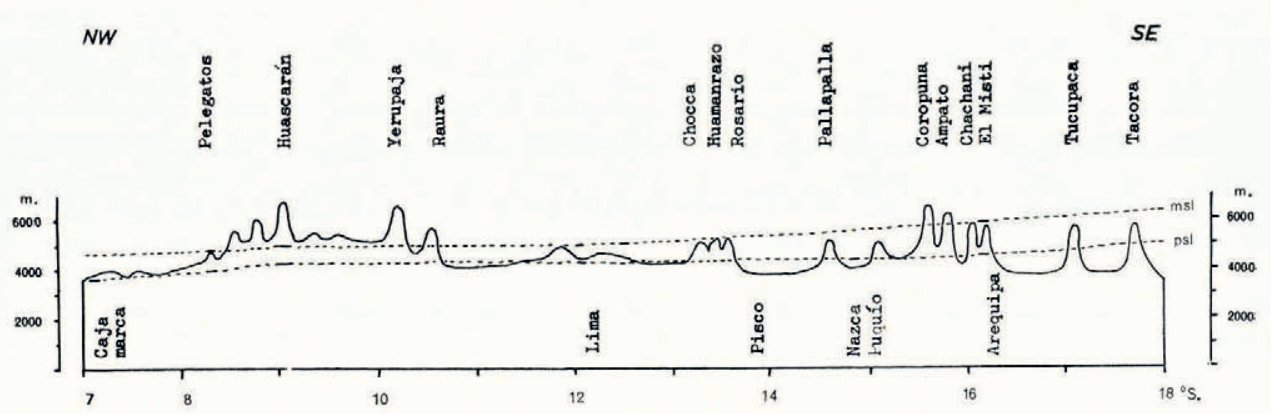

Fig. 6. Schematic north-west to south-east transect along the western Cordillera between lat. $7^{\circ}$ and ${ }_{1} 8^{\circ} S . M S L$ modern snow line, PSL Pleistocene snow line; vertical exaggeration times 35 . For the orientation of the profile see Figure I

Large-scale Variations of the Pleistocene Snow-line Depression and its Implications

In view of these observations from the western Cordillera (Fig. 6), a marked latitudinal variation of the snow line is indicated, between northern Peru (lat. $7^{-} 8^{\circ} \mathrm{S}$.), the region of La Oroya and Lima (lat. $12^{\circ} \mathrm{S}$.) and the region of Arequipa (lat. $16^{\circ} \mathrm{S}$.). The contemporary snow line rises by about $800 \mathrm{~m}$. from the latitude of Lima towards the arid regions of southern Peru. A further poleward rise in the snow line is borne out by the observations of Brüggen (1929) in northern Chile.

The poleward rise of the Pleistocene snow line appears to be considerably less than that of the modern snow line, namely, the depression of the Pleistocene snow line increases from about $700 \mathrm{~m}$. at the latitude of Lima to $\mathrm{I}, 300 \mathrm{~m}$. in the more arid regions of southern Peru. This trend also seems to continue into Chile. This pattern is analogous to the greater depression of the Pleistocene snow line evident in the hyperarid Pacific region when compared with the eastern flanks of the Andes (Fig. 4).

From the latitude of Lima northward into the Cordillera Blanca, the Pleistocene snow- 
line depression apparently remains about the same or it even decreases slightly. However, proceeding from the Cordillera Blanca farther northward into northern Peru, the Pleistocene snow-line depression seems to increase again (Fig. 6).

Figure 7 summarizes the altitudinal variation of the modern and the Pleistocene snow lines, as well as the elevation of the $0^{\circ} \mathrm{C}$. annual isotherm, in a schematic cross-section from about lat. $20^{\circ} \mathrm{N}$. to $20^{\circ} \mathrm{S}$. Wilhelmy (1957) has given an elevation of $4,600-4,700 \mathrm{~m}$. for the modern snow line in the Colombian Andes. From a variety of geomorphic phenomena, he has estimated the snow line in the Sierra Nevada de Santa Marta during the last glaciation at an elevation of $3,700-3,800 \mathrm{~m}$. In the Cordillera de Talamanca of Costa Rica, the Pleistocene snow line can be safely assessed at an elevation of 3,500 m. (Weyl, I955; Hastenrath, I963). On the volcanoes of the Mexican Meseta, the modern snow line occurs at about $4,800 \mathrm{~m}$. and the Pleistocene snow line is at 4,000 $\mathrm{m}$. (Weyl, r 956; Hastenrath, ig63). The elevation of the $0^{\circ} \mathrm{C}$. annual isotherm was computed from the radiosonde data for 1958-62, published in the Monthly Climatic Data for the World (U.S. Weather Bureau, I95863). It will be remembered that, due to the heating effect of the extensive mountain masses, the $o^{\circ} \mathrm{C}$. isotherm over the Andes may lie several hundred meters higher than in the free atmosphere.

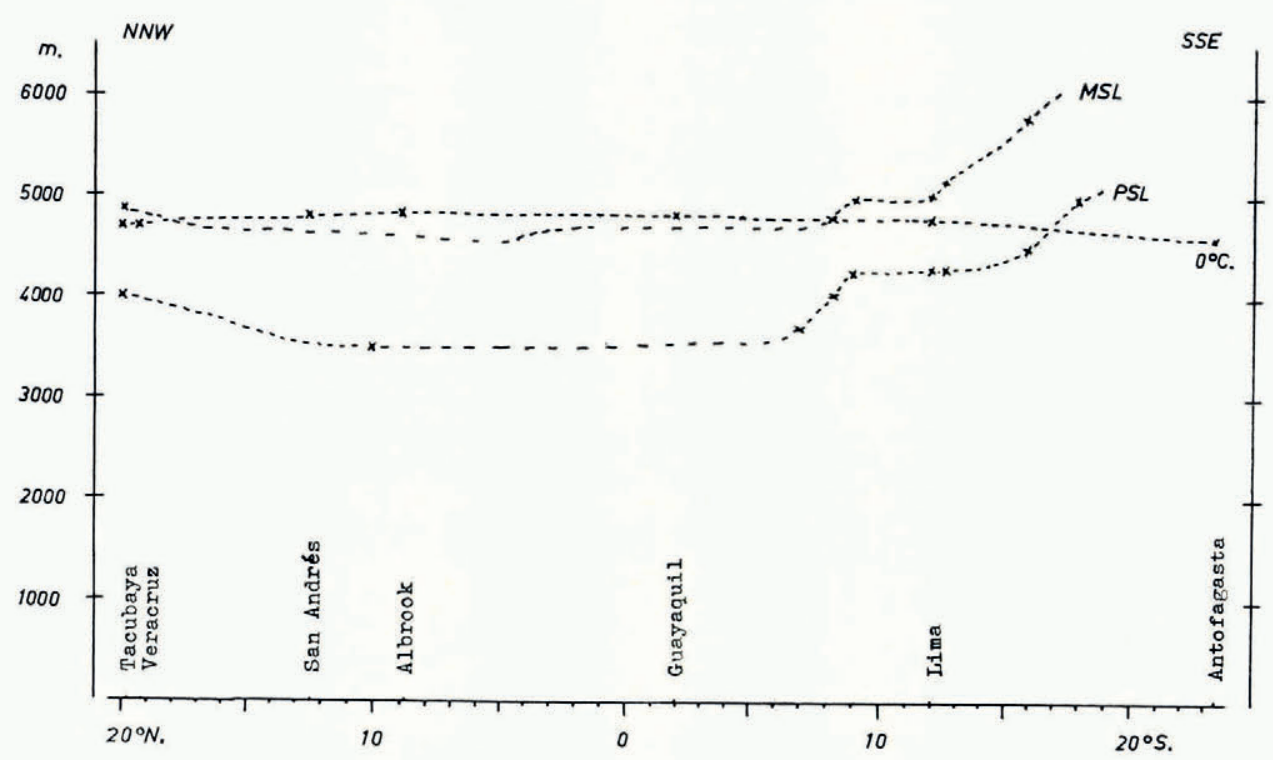

Fig. 7. Schematic north-north-west to south-south-east transect from about lat. $20^{\circ} \mathcal{N}$. to $20^{\circ} S$., showing the elevations of the modern snow line $(M S L)$, the Pleistocene snow line $(P S L)$ and the $o^{\circ} \mathrm{C}$. annual isotherm

The elevation of the $0^{\circ} \mathrm{C}$. annual isotherm is at about $4,800-5,000 \mathrm{~m}$. and it varies relatively little with latitude. The modern snow line in southern Peru, as well as in the hyperarid regions of northern Chile, is at elevations well above the $o^{\circ} \mathrm{C}$. isotherm. In about the latitude of Lima, the modern snow line approaches the elevation of the $0^{\circ} \mathrm{C}$. isotherm, while it drops below that level farther northward.

The Pleistocene snow line is close to the elevation of the present $o^{\circ} \mathrm{C}$. isotherm in northern Chile. Proceeding northward, the Pleistocene snow line drops monotonically to lower elevations, reaching its minimum of $3,500 \mathrm{~m}$. in the Cordillera de Talamanca of Costa Rica. 
A rise of the Pleistocene snow line by $500 \mathrm{~m}$. occurs from Costa Rica to the Mexican Meseta, and this appears to be partly due to the heating effect of the extensive mountain masses (e.g. Hastenrath, ig63).

The difference between the elevations of the modern and the Pleistocene snow lines is largest in the hyperarid regions of southern Peru and northern Chile. The Pleistocene snowline depression decreases northward, reaching a minimum in the Cordillera Blanca. Proceeding farther northward, the Pleistocene snow-line depression obviously increases again, apparently reaching another maximum in the Cordillera de Talamanca of Costa Rica, and it decreases again into southern Mexico.

The elevation of the snow line is basically a heat-budget problem. Within the tropics, seasonal variations of temperature are comparatively small and conditions can be expected to be less complicated than in higher latitudes. For the annual mean and as a first approximation, the equilibrium conditions of the snow line may be written:

and

$$
\begin{gathered}
\left(Q_{n}-Q_{b}\right)=\left(Q_{\text {melt }}+Q_{\text {subl. }}\right)+Q_{\text {sens. }} \\
Q_{\text {melt }} / L_{\text {melt }}+Q_{\text {subl. }} / L_{\text {subl. }}=P_{\text {snow. }}
\end{gathered}
$$

Here $Q_{n}$ is the net absorbed solar radiation at the snow surface, $Q_{b}$ the effective outgoing radiation, and the difference between the two terms is the radiation balance at the snow surface. $Q_{\text {sens. }}$ is the sensible heat transfer, which generally may be directed from ground to air or vice versa. $Q_{\text {melt }}$ is the heat used in melting and $Q_{\text {subl. }}$ is the heat used in sublimation of snow. $L_{\text {melt }}=80 \mathrm{cal} . /\left(\mathrm{g} . \mathrm{H}_{2} \mathrm{O}\right)$ is the latent heat of melting and $L_{\text {subl. }}=677 \mathrm{cal} . /\left(\mathrm{g} . \mathrm{H}_{2} \mathrm{O}\right)$, the latent heat of sublimation. $P_{\text {snow }}$ denotes the total precipitation in solid form.

Several years of radiosonde ascents over Lima and Antofagasta are available in the Monthly Climatic Data of the World (U.S. Weather Bureau, r 958-63). On the basis of these data and by using an Elsasser diagram (e.g. Johnson, 1954), an attempt was made to calculate the effective outgoing radiation at the Earth's surface, $Q_{b}$, for various elevations ranging from 3,000 to $7,000 \mathrm{~m}$. Similarly, an attempt was made to estimate the altitudinal variation of the net absorbed solar radiation, $Q_{n}$. The altitudinal variation of $Q_{b}$ is comparatively small and $Q_{n}$ increases with elevation. The altitudinal variation of the radiation balance does not play an essential role in the elevation of the snow line. Therefore, no estimates of $Q_{n}$ and $Q_{b}$ are reported here.

Generally speaking, the sensible heat transfer $Q_{\text {sens. }}$ need not be zero and it may be directed either upward or downward. Considering larger areas and the entire year, however, this term is assumed to be small and not to vary substantially with elevation.

With the restrictions given above, $\left(Q_{\text {melt }}+Q_{\text {subl. }}\right)$ does not vary substantially with elevation. The climatic snow line can be considered as the elevation where the snow lost through melting and ablation equals the total precipitation in solid form. It will be remembered that melting implies a heat expenditure almost one order of magnitude smaller than that needed for sublimation. The snow-line elevation will then depend essentially on the altitudinal variation of the ratio $Q_{\text {subl. }} / Q_{\text {melt }}$. Considering the daily cycle, this would greatly depend on the duration of temperature above freezing.

Howell (1953) found for a glacier of Cerro Huagaruancha in central Peru that about 95 per cent of the wastage takes place by melting. Although no precise elevation is given for this site, it definitely appears to lie at a lower elevation than the $0^{\circ} \mathrm{C}$. annual isotherm.

Troll (1943[a], [b]) analyzed the daily and annual cycle of temperature for various elevations on El Misti. These data indicate that, even at the comparatively high elevation of the snow line in arid southern Peru, there are several hours each day with temperatures above freezing, which means that melting will play an essential role.

At present, no reasonable quantitative estimates appear to be possible on the altitudinal variation of the ratio $Q_{\text {subl. }} / Q_{\text {melt }}$. Also, our knowledge of the precipitation conditions in the Peruvian Andes leaves much to be desired. This limits the possibility of reconstructing 
the Pleistocene temperature and precipitation conditions, on the basis of the snow-line depression.

Yet, some inferences are suggested from the larger-scale distribution of the Pleistocene snow-line depression. The large depression in the arid Pacific region of southern Peru, compared with the Amazonian slopes of the Andes and central Peru, suggests a substantial increase in precipitation. The elevation of the Pleistocene snow line relative to the present $0^{\circ}$ C. annual isotherm, on both the Pacific and the Amazonian sides of the Andes and in central Peru, indicates that this was associated with a decrease of temperature.

On the other hand, the large depression of the Pleistocene snow line in Costa Rica would require a considerable drop in temperature. It even appears that this depression could be explained by a marked decrease in temperature alone, although this might not be likely. From palynological studies in the area of Bogotá in Colombia (Van der Hammen, in press) a somewhat more humid climate can be inferred for the time of the last glaciation. A drop in the $o^{\circ} \mathrm{C}$. annual isotherm from its present elevation around $4,900 \mathrm{~m}$. to about the $3,500 \mathrm{~m}$. level corresponds to a decrease in temperature of about $7^{\circ} \mathrm{C}$., if the lapse-rate of temperature and the thermal effect of the mountain mass on the temperature field of the free atmosphere are assumed unchanged. However, the increased albedo due to a snow cover is expected to modify the thermal effect of the mountain mass. Changes in the lapse-rate of temperatures may also play a role. It therefore appears that in the latitude of northern Colombia and Costa Rica the Pleistocene cooling at sea-level may have been substantially less than $7^{\circ} \mathrm{C}$.

The Pleistocene snow-line depression was found to reach a minimum in about the latitude of northern Peru (Fig. 7). This depression would require a drop in temperature but, as it appears, not necessarily an increase in precipitation.

The Pleistocene cooling appears to have been most pronounced in the latitude of northern Colombia and Costa Rica, while the temperature drop seemingly decreased southward. A substantial increase in precipitation is postulated for the arid regions of southern Peru and an increase in precipitation may have been less pronounced in latitude; farther north. A cooling near the Equator, together with a more humid climate in somewhat higher latitudes, would appear compatible with Flohn's (1952) concept of a reinforcement of meridional circula. tions during the Pleistocene.

It appears possible that the circulation pattern during the Pleistocene in the American sector was characterized by a southward shift of the equatorial trough zone. This could imply for southern central America a greater prevalence of air masses originating from the higher latitudes of the Northern Hemisphere. In turn this would account for lower temperatures, though possibly associated with decreased precipitation, as was suggested in the above discussion. However, for the west coast of South America, a southward shift of the equatorial trough zonc would bring increased precipitation, as postulated above from the large-scale distribution of the Pleistocene snow-line depression. This would also appear to agree satisfactorily with the marked decrease in the Pleistocene snow-line depression from the Pacific slopes to the Amazonian side of the Andes.

\section{Evidence of Pleistocene Pluvial Phenomena}

From the above discussion of the Pleistocene snow-line depression, there are indications that the last glaciation in southern Peru was a period of a more humid climate. Kessler (1963) has come to a similar conclusion in his attempt to reconstruct the hydrology of the Altiplano during the climax of the last glaciation.

In the region of Arequipa and Mollendo, there is ample geomorphic evidence for a previously less arid climate. Fluviatile erosion forms (gullies) are filled with drifting sand, proving them to be fossil forms. In the Pampa de La Joya near Arequipa, channels several meters wide are found following the slope of the terrain. These "wadis" contain clearly 
fluviatile sediments and they are now covered with sand of acolian deposition. Fossil formations of caliche in the La Joya region also indicate an earlier less arid climate. No chronological determination of all these fossil geomorphic phenomena in the Arequipa region has, however, been possible so far.

\section{ACKNOWLedgements}

This study was partly supported by National Science Foundation grant GP-444. Discussions with R. A. Bryson, K. W. Butzer and F. Prohaska, of the University of Wisconsin, are gratefully acknowledged.

\section{MS. received 6 September 1966}

\section{REFERENCES}

Ahlfeld, F. 1946. Geología de Bolivia. Instituto del Museo de la Universidad Nacional de La Plata. Revista del Museo de La Plata, Nueva Serie, Tom. 3, Geología, No. 19.

Brüggen, J. 1929. Zur Glazialgeologie der chilenischen Anden. Geologische Rundschau, Bd. 20, Ht. I, p. I-35.

Eichler, A. 1952. Nieve y selva en Ecuador. Quito-Guayaquil, Ecuador, Editorial Bruno Moritz.

Flohn, H. 1952. Allgemeine atmosphärische Zirkulation und Paläoklimatologie. Geologische Rundschau, Bd. 4o, Ht. I, p. ${ }^{1} 53-78$.

Hastenrath, S. 1963. Über den Einfluss der Massenerhebung auf den Verlauf der Klima- und Vegetationsstufen in Mittelamerika und im südlichen Mexico. Geografiska Annaler, Vol. 45, No. 1, p. 76-83.

Heim, A. 1948. Wunderland Peru. Bern, Verlag Hans Huber.

Herzog, T. I914. Beiträge zur Kenntnis von Tektonik und Glazial der bolivianischen Ostkordilleren. Geologische Rundschau, Bd. 5, Ht. 5, p. 353-71.

Howell, W. E. 1953. Some measurements of ablation, melting, and solar absorption on a glacier in Peru. Trarsactions. American Geophysical Union, Vol. 34, No. 6, p. 883-88.

James, P. E. 1959. Latin America. New York, Odyssey Press.

Johnson, J. C. 1954. Physical meteorology. New York, Technology Press of M.I.T. and John Wiley and Sons Inc.

Kessler, A. 1963. UUber Klima und Wasserhaushalt des Altiplano (Bolivien, Peru) während des Hochstandes der letzten Vereisung. Erdkunde, Bd. 17, Ht. 3-4, p. I65-73.

Kinzl, H. 1935. Gegenwärtige und eiszeitliche Vergletscherung in der Cordillera Blanca (Peru). Verhandlungen des Deutschen Geographentages Bad Nauheim, 1934, p. 41-56.

Kinzl, H. r949. Die Vergletscherung in der Südhälfte der Cordillera Blanca (Peru). Zeitschrift für Gletscherkunde und Glazialgeologie, Bd. 1, Ht. 1, p. 1-28.

Kinzl, H. In press. La glaciación actual y pleistocénica de los Andes Centrales. Proceedings of the UNESCO Symposium on Geo-Ecology of the Mountainous Regions of the Tropical Americas, Mexico City, I-3 August I966.

Kinzl, H., and Schneider, E. I950. Cordillera Blanca (Peru). Innsbruck, Universitätsverlag.

Machatschek, F. 1944. Diluviale Hebung und eiszeitliche Schneegrenzdepression. Geologische Rundschau, Bd. 34, Ht. $7-8$, p. $327-4$ I.

Newell, N. D. I949. Geology of the Lake Titicaca region, Peru and Bolivia. Geological Society of America. Memoir 36.

Tricart, J. 1965. Observations on the Quaternary firn line in Peru. Fournal of Glaciology, Vol. 5, No. 42, p. 857-63.

Troll, C. 1929. Die Cordillera Real. Zeitschrift der Gesellschaft für Erdkunde zu Berlin, Bd. 63, Ht. 4, p. $279-317$.

Troll, C. 1931. Die Übersichtskarte der Cordillera Real. Zeitschrift der Gesellschaft für Erdkunde zu Berlin, Bd. 65 , Ht. 2, p. $117^{-24}$.

Troll, C. 1943[a]. Die Frostwechselhäufigkeit in den Luft- und Bodenklimaten der Erde. Meteorologische Zeitschrift, Bd. 60 , Ht. 5 , p. $16 \mathrm{I}-7 \mathrm{r}$.

Troll, C. 1943[b]. Thermische Klimatypen der Erde. Petermanns Geographische Mitteilungen, Jahrg. 89, Ht. 3-4, p. $8 \mathrm{I}-89$.

Troll, C., and Finsterwalder, R. 1935. Die Karten der Cordillera Real und des Talkessels von La Paz. Petermanns Geographische Mitteilungen, Jahrg. 81, Ht. 11, p. 393-99.

U.S. Weather Bureau. 1958-63. Monthly Climatic Data for the World, 1958-62.

Van der Hammen, T. In press. Climatic and vegetational succession in the equatorial Andes of Colombia. Proceedings of the UNESCO Symposium on Geo-Ecology of the Mountainous Regions of the Tropical Americas, Mexico City, I-3 August 1966 .

Weyl, R. I955. Vestigios de una glaciación del pleistoceno en la Cordillera de Talamanca, Costa Rica, C.A. Instituto Geográfico de Costa Rica, Informe Trimestral, Julio a Septiembre 1955, p. 9-32.

Weyl, R. 1956. Geologische Wanderungen durch Costa Rica. Natur und Volk (Frankfurt a.M.), No. 86.

Wilhelmy, H. 1957. Eiszeit und Eiszeitklima in den feuchttropischen Anden. Petermanns Geographische Mitteilungen. Ergänzungsheft 262 , p. $281-310$. 